JPPMS, Vol. 3, No. 2, 2019

Jurnal Penelitian Pendidikan Matematika dan Sains

http://journal.unesa.ac.id/index.php/jppms/

\title{
KEMAMPUAN KOMUNIKASI MATEMATIS SISWA DALAM MENYELESAIKAN SOAL STATISTIKA DITINJAU DARI KECERDASAN INTRAPERSONAL DAN INTERPERSONAL
}

\author{
Oleh: \\ Ulfatun Nisa ${ }^{1}$, Rini Setianingsih ${ }^{2}$ \\ ${ }^{1,2}$ Jurusan Matematika FMIPA Universitas Negeri Surabaya \\ ulfatunnisa16030174013@unesa.ac.id \\ 2rinisetianingsih@unesa.ac.id
}

\begin{abstract}
Abstrak - Kemampuan komunikasi matematis dalam belajar matematika sangat dibutuhkan oleh siswa karena melalui komunikasi, siswa dapat mengekspresikan ide-ide atau pikiran mereka tentang matematika secara lisan ataupun tulisan. Sementara itu, ada perbedaan kecerdasan siswa, salah satunya kecerdasan intrapersonal dan interpersonal, yang memungkinkan adanya beberapa perbedaan kemampuan komunikasi tulis dan lisan mereka dalam menyelesaikan soal statistika. Penelitian ini bertujuan untuk mendeskripsikan kemampuan komunikasi matematis siswa dalam menyelesaikan soal statistika berdasarkan tingkat kecerdasan intrapersonal dan interpersonal yang dimiliki oleh siswa. Instrumen yang digunakan dalam penelitian ini adalah angket kecerdasan intrapersonal dan interpersonal, soal tes kemampuan komunikasi matematis, dan wawancara. Subjek dalam penelitian ini adalah empat siswa, dengan satu siswa diantaranya memiliki kecerdasan intrapersonal dan interpersonal kategori tinggi, satu siswa memiliki kecerdasan intrapersonal tinggi namun kecerdasan interpersonal rendah, satu siswa dengan tingkat kecerdasan intrapersonal rendah namun kecerdasan interpersonal tinggi, dan satu siswa lainnya memiliki tingkat kecerdasan yang rendah pada intrapersonal dan interpersonal. Pengelompokan kecerdasan interpersonal dan intrapersonal ditentukan melalui skor pada instrumen pengukuran kecerdasan intrapersonal dan interpersonal masing-masing siswa. Keempat siswa tersebut diberikan tes kemampuan komunikasi matematis untuk memperoleh data kemampuan komunikasi matematis. Berdasarkan deskripsi dan hasil analisis dalam penelitian ini, menunjukkan bahwa kecerdasan intrapersonal dan interpersonal dapat mempengaruhi siswa saat menyelesaikan soal statistika. Oleh karena itu penting bagi siswa dan guru untuk mengetahui kemampuan komunikasi matematis agar dapat meningkatkan pemahaman dan kemampuan dalam menyelesaikan soal statistika.

Kata Kunci: Kemampuan Komunikasi Matematis, Soal Statistika, Kecerdasan Intrapersonal dan Interpersonal

Abstract - Mathematical communication skills are needed by students in learning mathematics because through communication, students can express their ideas or thoughts about mathematics in writing or orally. Meanwhile, there are differences in student intelligence, one of which is intrapersonal and interpersonal intelligence, which allows for some differences in their written and verbal communication skills in solving statistical problems. This study aims to describe the mathematical communication skills of students in solving statistical problems based on the level of intrapersonal and interpersonal intelligence possessed by students. The instruments used in this study were intrapersonal and interpersonal intelligence questionnaires, mathematical communication skills test questions, and interviews. The subjects in this study were four students, one student with high intrapersonal and interpersonal intelligence, low students with low intrapersonal and interpersonal intelligence, one student with low intrapersonal and high interpersonal intelligence, and one student with low intrapersonal and interpersonal intelligence. The grouping of intrapersonal and interpersonal intelligence is determined through each student's intrapersonal and interpersonal intelligence questionnaire. The four students were given a mathematical communication ability test to obtain data on mathematical communication skillsBased on the description and analysis results in this study, it shows that intrapersonal and interpersonal intelligence can influence students when solving statistical problems. Therefore it is important for students and teachers to know the mathematical communication skills in order to improve understanding and ability to solve statistical problems..

Keywords: Mathematical Communication Skills, Statistics Questions, Intrapersonal and Interpersonal Intelligence
\end{abstract}




\section{Pendahuluan}

Perkembangan ilmu pengetahuan dan teknologi yang menjadi keniscayaan di era globalisasi menuntut manusia dengan daya pikir tinggi, antara lain kemampuan dalam bidang matematika. Siswa dituntut untuk belajar secara aktif, kreatif, dan inovatif pada pembelajaran matematika. Pembelajaran yang demikian menjadikan siswa mampu memahami materi yang diajarkan yang selanjutnya dapat mengaplikasikannya dalam kehidupan mereka.

Berkenaan dengan hal tersebut, Partnership for 21st Century Skills (dalam Setianingsih, 2016) menegaskan bahwa penting bagi semua orang untuk memiliki keterampilan dasar, yang dikenal dengan 4C yaitu critical and problem solving skills, collaboration skills, communication skills, dan creativity and innovation skills.

Selaras dengan Partnership for 21st Century Skills, dinyatakan dalam Permendikbud Nomor 21 tahun 2016 tentang standar isi kurikulum 2013 bahwa kompetensi yang ditagih dalam kegiatan belajar mengajar mencangkup tiga ranah yaitu sikap, pengetahuan, dan keterampilan. Salah satu keterampilan yang dituntut untuk dikuasai oleh siswa baik dari jenjang sekolah dasar maaupun menengah adalah memiliki keterampilan komunikasi yang baik. Oleh karena itu, keterampilan komunikasi adalah keterampilan yang penting dan perlu dipelajari oleh siswa.

"Terdapat dua hal yang menjadi alasan pentingnya kemampuan komunikasi dalam pembelajaran matematika yaitu: (1) matematikan adalah bahasa/ mathematics is language; matematika tidak hanya sekedar alat bantu berpikir (a tool to aid thinking), untuk mendapatkan pola, atau memecahkan masalah, namun juga matematika merupakan alat untuk menyatakan berbagai ide dengan jelas, ringkas dan tepat, serta (2) mathematics learning as social activity, matematika sebagai aktivitas sosial dalam pembelajaran, yang memungkinkan interaksi antar siswa, guru dan siswa melalui komunikasi yang merupakan bagian penting untuk memelihara dan mengembangkan potensi matematika siswa" menurut Baroody (dalam Kadir, 2008).

Berdasarkan uraian di atas dapat diketahui bahwa salah satu penekanan yang harus disajikan dalam mempelajari matematika adalah komunikasi. Bahkan Morrale dan Pearson (2008) menyebutkan bahwa komunikasi dipandang sebagai pusat dari tujuan sistem pendidikan. Kemampuan komunikasi meliputi kemampuan dalam hal menyampaikan pemikiran dengan jelas secara lisan maupun tertulis, menyampaikan pendapat dan perintah secara jelas, dan mampu memotivasi orang lain melalui keterampilan berbicara (Zubaidah, 2016).

Oleh karena itu, kemampuan komunikasi dalam matematika khususnya dalam pembelajaran matematika menjadi tuntutan khusus. Seperti dalam NCTM (2000) yang menyebutkan "Communication is an essential part of mathematics and mathematics education". Komunikasi adalah esensial part dari matematika dan pembelajarannya.

"Komunikasi matematis dapat berupa: (1) Menyatakan ide-ide matematika melalui tulisan, lisan, dan memperagakannya serta menggambarkannya secara visual; (2) Memahami, menginterpretasikan, dan mengevaluasi ide-ide matematika baik secara lisan maupun dalam bentuk visual lainnya; (3) Menggunakan istilah, notasi matematika dan strukturnya untuk menggambarkan hubungan, menyatakan ide, dan menyajikan model-model situasi" menurut NCTM (1989).

Dalam hal ini, kemampuan komunikasi matematis dibagi menjadi dua jenis, yaitu: (1) kemampuan komunikasi matematis tulis yang meruoakan kecakapan siswa dalam menyampaikan dan menerima ide atau pikiran matematika yang dimiliki dalam bentuk tulisan; serta (2) kemampuan komunikasi matematis lisan merupakan kecakapan siswa dalam mengemukakan dan mencerna ide atau pikiran matematika yang dimiliki menggunakan kata-kata.

Pada kurikulum 2013, pemerintah mengharapkan pembelajaran tidak hanya bersumber dari guru, namun juga dituntut keaktifan siswa dalam proses pembelajaran. Pembelajaran seharusnua direncanakan untuk membiasakan siswa dalam mengonstruksi sendiri pengetahuannya, sehingga siswa dapat mengkomunikasikan hasil berpikirnya baik kepada guru, teman, ataupun terhadap konsep materi matematika itu sendiri, yang berarti siswa diharapkan mampu menyelesaikan soal yang diberikan.

Selama ini statistika telah diterapkan di berbagai bidang kehidupan. Statistika telah menjadi pedoman baik dalam pengumpulan data atau informasi, pengolahan data, penyajian data maupun dalam membuat keputusan. Hal ini sejalan dengan pendapat Moore (1997) yang mengatakan bahwa statistika merupakan alat yang dapat digunakan untuk menyelesaikan masalah yang senantiasa terjadi dalam kehidupan seharihari, di tempat kerja, maupun dalam ilmu pengetahuan. Dalam dunia ekonomi khususnya kegiatan pemasaran produk, statistika berguna dalam menyajikan data-data statistik mengenai 
jumlah penduduk suatu daerah, kriteria penduduk berdasarkan jenis kelamin atau usia, pekerjaan dan penghasilan penduduk di suatu daerah, dan sebagainya. Di Jepang, statistika digunakan dalam mendesain dan memasarkan produknya seperti motor, mobil, dan berbagai barang elektronik lainnya. Prestasi Jepang dalam memasarkan produk salah satunya dilator belakangi oleh kesuksesan pendidikan di negara Jepang pada materi statistika yang telah diberikan secara luas mulai sekolah menegah atas hingga perguruan tinggi (Boediono dan Koster, 2004).

Melihat pentingnya peran statistika dalam kehidupan sehari-hari, maka sudah semestinya pembelajaran statistika di kelas mendapatkan perhatian khusus dari guru. Guru diharapkan mampu menciptakan aktivitas pembelajaran statistika yang mudah diikuti dan dipahami. Pernyataan tersebut didukung oleh Rumsey (2002) yang mengatakan bahwa tujuan pembelajaran statistika adalah untuk membuat siswa memahami statistika dengan baik, yaitu dapat memperoleh informasi dari data yang tersedia, mampu memberikan kritik dan membuat keputusan berdasarkan informasi yang diperoleh, serta mampu melakukan penelitian.

Beberapa penelitian menunjukkan adanya kesulitan yang dialami siswa saat mempelajari materi statistika terutama pada statistika data berkelompok, diantaranya: (1) penelitian yang dilakukan oleh Awaludin (2017) mengenai analisis kesulitan siswa SMA Batik 1 Surakarta kelas XI dalam mempelajari ukuran tendensi sentral pada data berkelompok. Hasil penelitian Awaludin menunjukkan bahwa siswa SMA Batik 1 Surakarta kelas XI tersebut masih mengalami kesulitan dalam memahami konsep dan menerapkan rumus dalam menyelesaikan soal. (2) penelitian yang dilakukan oleh Saiman (2016) mengenai analisis kesulitan siswa MAN Langsa Aceh dalam belajar statistika khususnya pada histogram. Hasil penelitian Saiman menunjukkan bahwa terdapat 2 kesulitan utama siswa dalam membangun, menginterpretasi, dan menggunakan histogram di berbagai konteks, yaitu siswa mengalami kendala saat akan meletakkan variabel pada sumbu datar dan sumbu tegak, serta siswa mengalami kendala dalam menginterpretasi grafik histogram sehingga siswa cenderung melihat sumbu tegak dan membandingkan perbedaan ketinggian bar ketika membandingkan variasi bantuan dua buah histogram. Berdasarkan dua penelitian mengenai analisis kesulitan siswa saat mempelajari statistika data berkelompok, diharapkan guru dapat menjadi fasilitator untuk mengatasi kesulitan belajar yang dialami siswa. Berdasarkan hasil penelitian yang telah dilakukan oleh Laely Suci Handayani, dkk.
(2016:51) menunjukkan bahwa kebanyakan siswa masih belum dapat menghubungkan ide-ide yang telah diperolehnya sehingga mereka tidak mampu mencari penyelesaian soal yang diberikan. Berdasarkan penelitian yang telah dilakukan oleh Kaselin, dkk. (2017:122) diketahui bahwa kemampuan kemampuan komunikasi matematis siswa masih rendah.

Tinggi atau rendahnya kemampuan komunikasi matematika siswa ditentukan oleh beberapa faktor, salah satunya adalah perbedaan kecerdasan yang dimiliki oleh setiap siswa. "Dalam diri manusia terdapat spektrum kecerdasan yang luas. Spektrum kecerdasan tersebut mencakup tujuh jenis kecerdasan, yaitu kecerdasan verbal, kecerdasan visual, kecerdasan logis-matematis, kecerdasan musikal, kecerdasan kinestetik, kecerdasan intrapribadi (Intrapersonal), dan kecerdasan interpribadi (Interpersonal)" menurut Lwin, dkk. (2008).

Dalam penelitian ini, kecerdasan siswa ditinjau pada aspek Interpersonal dan Intrapersonal. Tinggi rendahnya kecerdasan Interpersonal dan Intrapersonal dalam pembelajaran di kelas sangat penting untuk diterapkan dengan tujuan agar dapat diaplikasikan dalam kehidupan nyata. Kecerdasan Intrapersonal adalah kemampuan memahami diri sendiri dan bertanggung jawab akan dirinya sendiri. Kecerdasan Interpersonal adalah kemampuan untuk berhubungan dengan orang lain di sekitar kita (Lwin dkk, 2008).

Safaria (2005) menyebutkan karakteristik seseorang dengan tingkat kecerdasan interpersonal yang tinggi yaitu, (1) mampu membangun dan menciptakan hubungan sosial baru dengan orang lain secara efektif, (2) dapat berempati terhadap kondisi orang lain, (3) Dapat mempertahankan hubungan sosialnya dengan orang lain secara efektif, (4) dapat menyadari baik komunikasi verbal maupun nonverbal yang orang lain munculkan, (5) dapat memunculkan win-win solution ketika menyelesaikan masalah atau persoalan yang terjadi dalam hubungan sosialnya dengan orang lain, serta (6) mempunyai kemampuan komunikasi yang meliputi keterampilan mendengarkan , berbicara, dan menulis secara efektif.

Berbeda dengan kecerdasan Interpersonal, siswa dengan kecerdasan Intrapersonal yang tinggi akan mampu memahami kemampuan dirinya sendiri dan bersifat mandiri, mereka akan belajar dengan cara mereka sendiri. Oleh karena itu komunikasi yang dilakukan oleh siswa dengan kecerdasan Intrapersonal yang tinggi biasa dituangkan dalam bentuk tulisan, cenderung pasif dalam berbicara, dalam hal ini kemampuan komunikasi lisannya kurang. Maka dari itu, 
kecerdasan Intrapersonal dan kecerdasan Interpersonal yang dimiliki siswa akan berpengaruh terhadap tinggi rendahnya kemampuan komunikasi matematis tulis dan lisannya.

Berdasarkan uraian di atas, maka tujuan penelitian ini adalah untuk mendeskripsikan kemampuan komunikasi matematis tulis dan lisan siswa dengan kecerdasan intrapersonal dan interpersonal dalam menyelesaikan soal statistika.

\section{Metode}

Penelitian ini merupakan penelitian deskriptif menggunakan pendekatan kualitatif. Subjek dari penelitian ini adalah 30 siswa kelas XII SMA Negeri 5 Madiun. Instrumen yang digunakan berupa angket yang disajikan dalam Google form, dilanjutkan dengan memberikan lembar tes kemampuan untuk mengukur kemampuan komunikasi matematis dan wawancara kepada siswa yang telah terpilih menjadi subjek yang dilakukan secara online. Untuk pengumpulan data, 30 siswa tersebut diberikan angket kecerdasan intrapersonal dan interpersonal. Setelah itu dipilih 4 subjek penelitian, dengan satu siswa diantaranya memiliki kecerdasan intrapersonal dan interpersonal kategori tinggi, satu siswa memiliki kecerdasan intrapersonal tinggi namun kecerdasan interpersonal rendah, satu siswa dengan tingkat kecerdasan intrapersonal rendah namun kecerdasan interpersonal tinggi, dan satu siswa lainnya memiliki tingkat kecerdasan yang rendah pada intrapersonal dan interpersonal. Kemudian empat subjek tersebut diberikan tes kemampuan komunikasi matematis yang berupa soal statistika sub bab pemusatan data kelompok dan diwawancarai mengenai penyelesaian tes kemampuan komunikasi matematis tersebut.

Untuk alur penelitian yang lengkap, dari awal yaitu pemilihan subjek hingga mendapatkan hasil, dapat dilihat pada Gambar 1

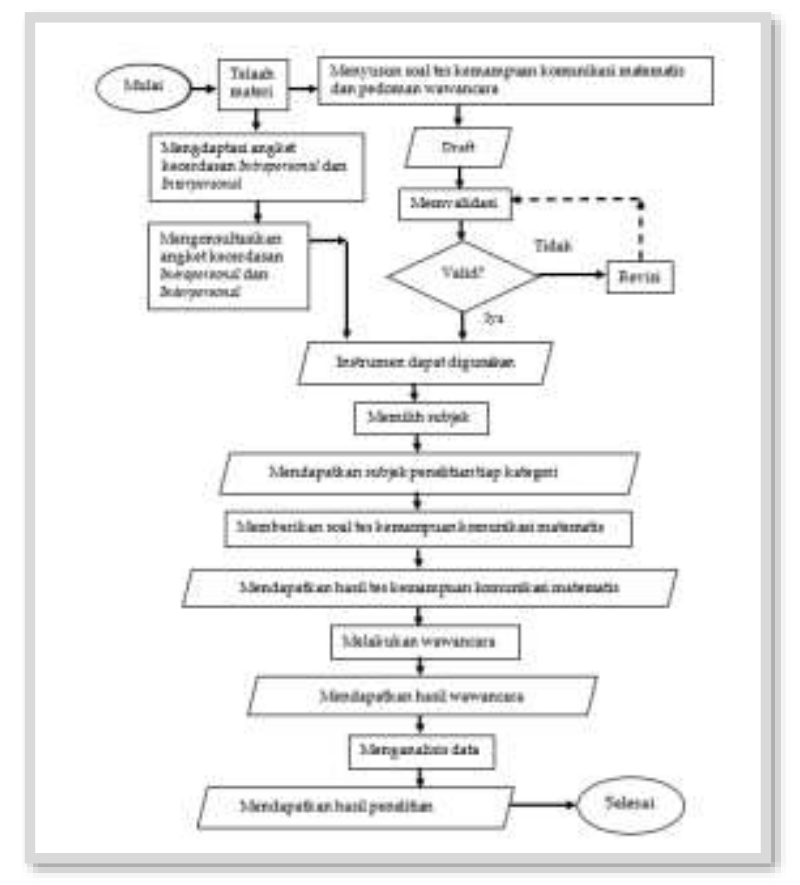

Gambar 1 Alur Penelitian

Dalam penelitian ini data yang akan diperoleh yaitu data hasil angket kecerdasan intrapersonal dan interpersonal, data hasil tes kemampuan komunikasi matematis, dan data hasil wawancara. Data hasil angket kecerdasan intrapersonal dan interpersonal digunakan untuk mengelompokkan subjek berdasarkan skor kecerdasan intrapersonal dan interpersonal yang dimiliki siswa. Angket kecerdasan intrapersonal dan interpersonal yang digunakan peneliti berupa angket tertutup. Penelitian ini menggunakan instrumen berupa angket berbentuk rating scale (rating bertingkat) yang diadaptasi dan berisi pernyataan mengenai kecerdasan intrapersonal dan interpersonal yang merujuk pada konsep yang dikemukakan Barber (2005) yaitu Positive Intrapersonal and Interpersonal Functioning dimana variabel kecerdasan intrapersonal yang mencakup aspek harga diri (self esteem), pengambilan perspektif (perspective taking) dan empati. Variabel lain yaitu kecerdasan interpersonal yang mengandung aspek inisiatif sosial (social initiative), hubungan dengan teman sebaya (peer connection), komunikasi dengan ibu dan ayah. Pengelompokan kecerdasan 
intrapersonal dan interpersonal berdasarkan Barber (2005) siswa dapat dikatakan memiliki kecerdasan intrapersonal dan intrapersonal tinggi jika, $x \geq 80$, sedangkan siswa dapat dikatakan memiliki kecerdasan intrapersonal dan intrapersonal jika, $70 \leq \mathrm{x}<80$ untuk kecerdasan sedang, dan $\mathrm{x}<70$ untuk kecerdasan rendah, dengan $\mathrm{x}$ adalah nilai angket siswa.

Peneliti menggunakan angket Barber namun dengan beberapa perbedaan antara lain:

Angket yang digunakan oleh Barber berisi 55 butir (pernyataan dan pertanyaan) berbahasa Inggris yang terdiri dari 24 (pernyataan) tentang intrapersonal dan 31 (pernyataan dan pertanyaan) tentang interpersonal, sedangkan peneliti menggunakan angket berisi 50 butir (pernyataan) berbahasa Indonesia yang terdiri dari 25 (pernyataan) tentang intrapersonal dan 25 (pernyataan) tentang interpersonal. Penjelasan tentang pernyataan yang dibuang ada pada poin e.

Rating yang digunakan Barber terdiri dari angka 1 sampai 5, sedangkan peneliti menggunakan rating 1 sampai 4 yaitu Sangat Tidak Setuju (STS), Tidak Setuju (TS), Setuju (S), dan Sangat Setuju (SS). Poin ke 3 yaitu Ragu-Ragu (RR) dihapus agar hasil yang didapatkan tidak bias.

Pada poin pernyataan ke-30 Barber yang berbunyi "I actively participate in the school newspaper or yearbook" tidak relevan dengan penelitian yang dilakukan oleh peneliti, dikarenakan lokasi penelitian yang digunakan oleh peneliti adalah SMA Negeri 5 Madiun dimana di sekolah tersebut tidak terdapat majalah sekolah dan buku tahunan disusun oleh guru dan staf saja. Oleh karena itu, poin pernyataan ke-30 diganti dengan
"Saya lebih suka bekerja dalam kelompok daripada sendiri".

Pada poin pertanyaan ke-40 Barber yang berbunyi "How often do you and this friend go over to each other's houses?" dipecah menjadi 2 pernyataan pada penelitian ini agar mendapat hasil jawaban yang lebih rinci yaitu poin 40 berbunyi "Saya sering bermain ke rumah teman dekat dan poin 41 yang berbunyi "Teman dekat jarang bermain ke rumah saya".

Pada aspek "Communication with Mother" dan "Communication with Father" yang dikemukakan oleh Barber memiliki pernyataan-pernyataan yang sama. Padahal tidak semua siswa memiliki orang tua lengkap, jika siswa yang menjawab angket adalah anak yatim atau piatu maka hasil yang didapat tidak akan valid. Oleh karena itu, padapeelitian ini kedua aspek digabung menjadi "Komunikasi dengan orang tua".

Data hasil tes kemampuan komunikasi matematis kemudian digunakan untuk mengetahui kemampuan komunikasi matematis siswa saat menyelesaikan soal yang diberikan. Data hasil tes kemampuan komunikasi matematis dianalisis menggunakan indikator komunikasi matematis. Pada penelitian ini indikator komunikasi matematis mengacu pada aktivitas komunikasi yang dinyatakan oleh OECD (2013) dan memerhatikan tiga aspek komunikasi yang dinyatakan oleh Rausch (2017) yaitu keakuratan, kelengkapan, dan kelancaran. Data hasil wawancara digunakan untuk mendapatkan informasi lebih lanjut mengenai penyelesaian tes kemampuan komunikasi matematis siswa saat mencari solusi penyelesaian. Berikut indikator kemampuan komunikasi matematis siswa.

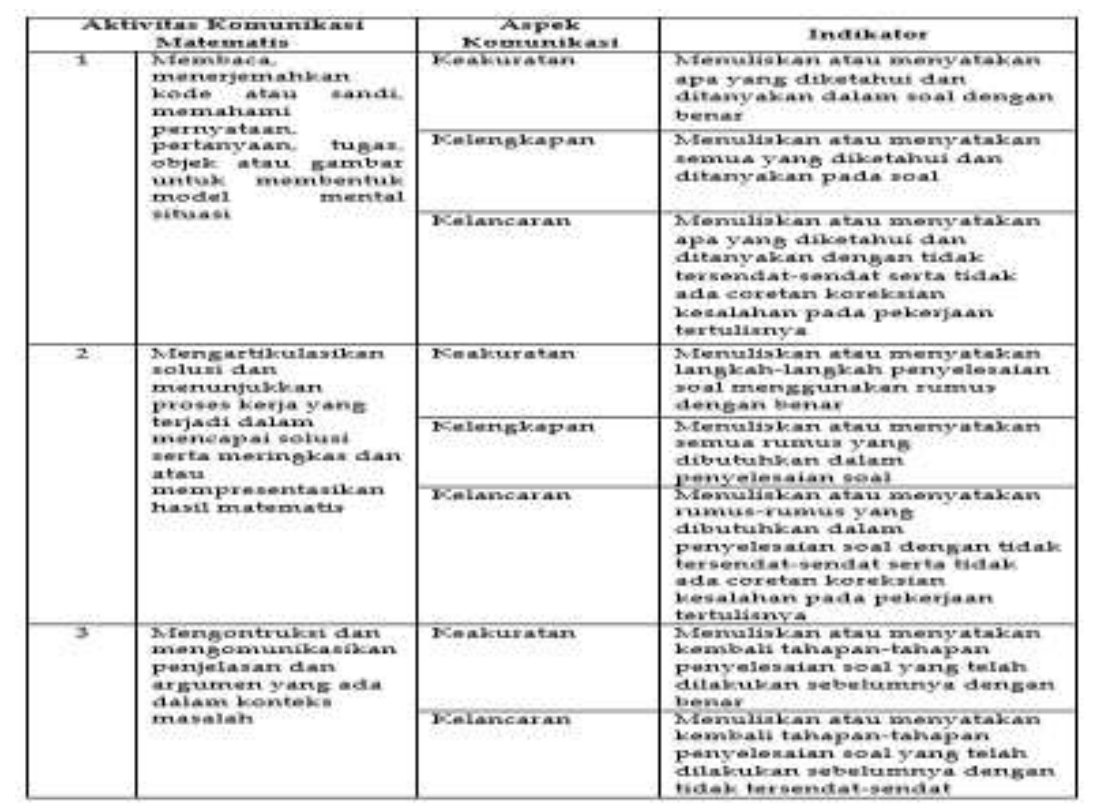

Gambar 2 Indikator Kemampuan Komunikasi Matematis 
Berikut merupakan soal tes kemampuan komunikasi matemati

1. Perhatikan histogram berikut!

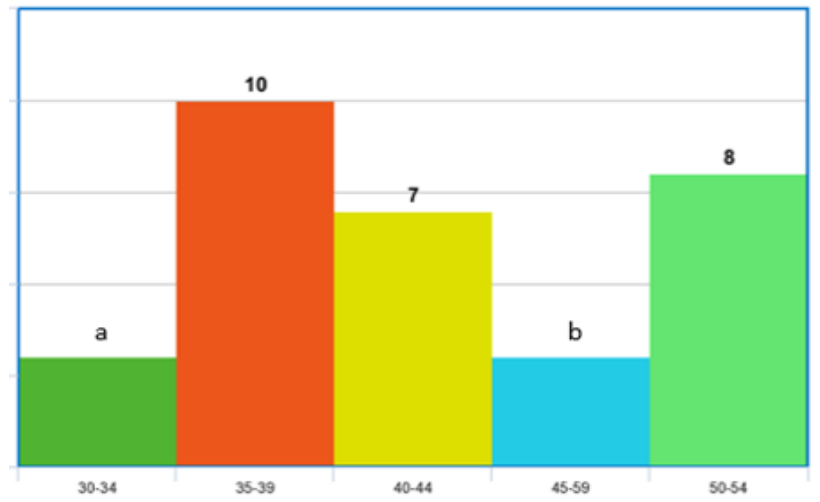

Jika diketahui mean dari data di atas adalah 43,6 dan a:b = 1:4, maka hitunglah median dan modusnya!

\section{Hasil dan Pembahasan Hasil Penelitian}

Berdasarkan analisis data angket kecerdasan Intrapersonal dan Interpersonal yang telah diberikan kepada 30 siswa. Pengelompokan kecerdasan Intrapersonal dan Interpersonal menggunakan ketentuan skor dari Barber (2005). Berdasarkan skor, siswa dikelompokkan ke dalam beberapa kategori.

Tabel 1 Hasil Tes dan Kategori Kecerdasan Siswa

\begin{tabular}{|l|l|l|l|l|l|}
\hline No & Nama & $\begin{array}{l}\text { Skor } \\
\text { Intra }\end{array}$ & $\begin{array}{l}\text { Kategor } \\
\text { i }\end{array}$ & $\begin{array}{l}\text { Skor } \\
\text { Inter }\end{array}$ & Kat \\
\hline 1 & ARB & 72 & Sedang & 83 & Tinggi \\
\hline 2 & KH & 85 & Tinggi & 96 & Tinggi \\
\hline 3 & ABV & 57 & Rendah & 62 & Rendah \\
\hline 4 & LAIP & 70 & Sedang & 80 & Tinggi \\
\hline 5 & DWN & 79 & Sedang & 89 & Tinggi \\
\hline 6 & DAP & 80 & Tinggi & 67 & Rendah \\
\hline 7 & DF & 78 & Sedang & 86 & Tinggi \\
\hline 8 & DA & 75 & Sedang & 75 & Sedang \\
\hline 9 & DP & 75 & Sedang & 85 & Tinggi \\
\hline 10 & RFKP & 80 & Tinggi & 89 & Tinggi \\
\hline 11 & NAS & 79 & Sedang & 88 & Tinggi \\
\hline 12 & AYH & 71 & Sedang & 73 & Sedang \\
\hline 13 & SMA & 69 & Rendah & 74 & Sedang \\
\hline 14 & VWK & 70 & Sedang & 75 & Sedang \\
\hline 15 & IJP & 65 & Rendah & 86 & Tinggi \\
\hline 16 & SNI & 81 & Tinggi & 87 & Tinggi \\
\hline 17 & ANP & 66 & Rendah & 82 & Tinggi \\
\hline 18 & SFC & 69 & Rendah & 64 & Rendah \\
\hline 19 & DAS & 69 & Rendah & 70 & Sedang \\
\hline 20 & CDA & 83 & Tinggi & 86 & Tinggi \\
\hline 21 & DIPA & 68 & Rendah & 68 & Rendah \\
\hline 22 & SSU & 70 & Sedang & 74 & Sedang \\
\hline 23 & RD & 73 & Sedang & 75 & Sedang \\
\hline 24 & NN & 69 & Rendah & 73 & Sedang \\
\hline 25 & MHP & 80 & Tinggi & 65 & Rendah \\
\hline 26 & ERB & 73 & Sedang & 73 & Sedang \\
\hline 27 & OKA & 77 & Sedang & 75 & Sedang \\
\hline 28 & NZN & 85 & Tinggi & 83 & Tinggi \\
\hline 29 & HR & 72 & Sedang & 72 & Sedang \\
\hline 30 & DKM & 67 & Rendah & 73 & Sedang \\
\hline
\end{tabular}


Berdasarkan tabel hasil tes terdapat 5 siswa yang termasuk kategori pertama, 2 siswa kategori kedua, 2 siswa kategori ketiga, dan 3 siswa kategori keempat. Untuk memilih 1 dari 5 kategori pertama, dalam hal ini dipilih KH karena memiliki jumlah nilai kecerdasan paling tinggi. Untuk memilih 1 dari 2 pada kategori kedua, dipilih MHP karena memiliki rentang nilai lebih besar dari pada
DAP. Untuk memilih 1 dari 2 kategori ketiga, dipilih IJP karena memiliki rentang nilai lebih besar dari pada ANP. Kemudian untuk pilihan 1 dari 3 pada kategori keempat, dipilih ABV karena memiliki jumlah nilai kecerdasan paling rendah. Dengan demikian didapatkan subjek penelitian Disajikan pada Tabel 2.

Tabel 2 Daftar Subjek Penelitian

\begin{tabular}{|l|l|l|l|l|l|}
\hline No & Nama & Kode & $\begin{array}{l}\text { Skor } \\
\text { Intra }\end{array}$ & $\begin{array}{l}\text { Skor } \\
\text { Inter }\end{array}$ & $\begin{array}{l}\text { Kategori } \\
\text { Kecerdasan } \\
\text { (Intra-Inter) }\end{array}$ \\
\hline 1 & KH & STT & 85 & 96 & Tinggi-Tinggi \\
\hline 2 & MHP & STR & 80 & 65 & Tinggi-Rendah \\
\hline 3 & IJP & SRT & 65 & 86 & Rendah-Tinggi \\
\hline 4 & ABV & SRR & 57 & 62 & Rendah-Rendah \\
\hline
\end{tabular}

Keterangan:

STT: Subjek dengan tingkat kecerdasan intrapersonal dan interpersonal tinggi.

STR: Subjek dengan tingakt kecerdasan intrapersonal tinggi namun kecerdasan interpersonal rendah.

SRT: Subjek dengan tingkat kecerdasan intrapersonal rendahnamun kecerdasan
SRR: Subjek dengan kecerdasan intrapersonal dan interpersonal rendah.

Jawaban tes matematika dan hasil wawancara dikodekan oleh peneliti untuk mengatur data dengan lebih mudah. Kode hasil tes matematika disajikan pada Tabel 3. interpersonal tinggi.

Tabel 3 Kode Penyajian Hasil Tes Matematika

\begin{tabular}{|c|l|}
\hline Kode & \multicolumn{1}{c|}{ Keterangan } \\
\hline Sab-y T & $\begin{array}{l}\text { Informasi yang disajikan oleh subjek secara tertulis dengan tingkat kecerdasan } \\
\text { intrapersonal a dan tingkat kecerdasan interpersonal b urutan ke-y }\end{array}$ \\
\hline
\end{tabular}

Kemudian, untuk kode hasil wawancara disajikan pada Tabel 4 berikut

Tabel 1 Kode Penyajian Hasil Wawancara

\begin{tabular}{|l|l|}
\hline Kode & Keterangan \\
\hline P-y & Pertanyaan ke-y yang disampaikan oleh peneliti \\
\hline Sab-y & $\begin{array}{l}\text { Informasi yang disajikan oleh subjek secara lisan dengan tingkat kecerdasan } \\
\text { intrapersonal a dan tingkat kecerdasan interpersonal b urutan ke-y }\end{array}$ \\
\hline
\end{tabular}

1. Analisis data hasil tes matematika untuk menemukan kemampuan komunikasi Gambar di bawah ini merupakan gambar hasil tes matematika tulis siswa. matematika yang dituliskan oleh subjek STT

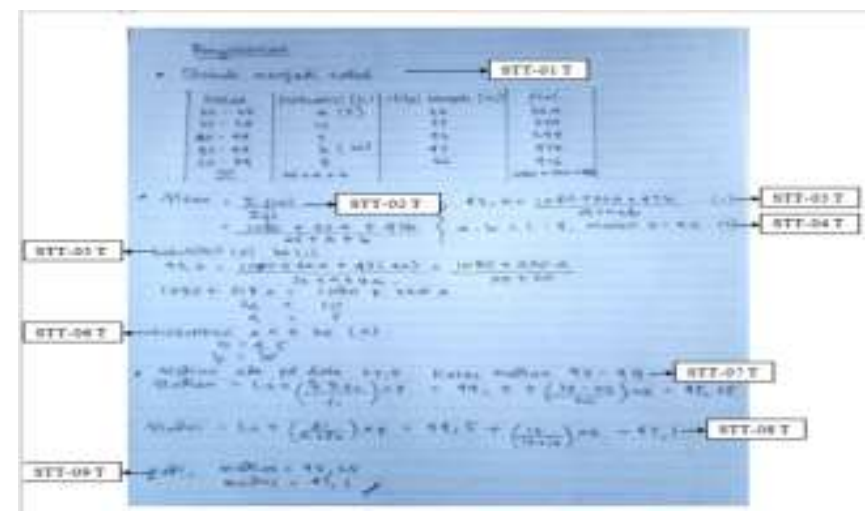

Gambar 2 Hasil Tes Matematika STT 
Pada lembar jawaban di atas, STT tidak menulis apa yang diketahui dan apa yang ditanyakan. STT menuliskan langkah-langkah penyelesaian soal menggunakan rumus secara akurat dan lengkap (STT-02 T, STT-07 T, STT-8 T). STT menuliskan tahapan-tahapan penyelesaian soal yang telah dilakukan secara akurat dan lengkap (STT-01 T, STT-03 T, STT-04 T, STT-05 T, STT-6 T, STT-9
T). Kemudian, STT mengerjakan tes matematika dengan tepat waktu, itu berarti STT melakukan langkah-langkah penyelesaian soal yang diberikan dengan lancar. Dengan langkah yang sama dan analisis yang sama seperti analisis STT sebelumnya, peneliti mendapatkan hasil analisis STR, SRT, SRR. Hasil analisis dapat dilihat pada Tabel 5.

Tabel 5 Hasil Ananisis Tes Matematika Tulis

\begin{tabular}{|c|c|c|c|c|}
\hline \multirow{2}{*}{ Indikator } & \multicolumn{4}{|c|}{ Kategori Kecerdasan Intrapersonal-Interpersonal } \\
\hline & STT & STR & SRT & SRR \\
\hline \multirow{3}{*}{$\begin{array}{l}\text { Menuliskan apa yang diketahui dan } \\
\text { ditanyakan dalam soal yang diberikan }\end{array}$} & Tidak akurat & Tidak akurat & Tidak akurat & Tidak akurat \\
\hline & Tidak lengkap & Tidak lengkap & Tidak lengkap & Tidak lengkap \\
\hline & Tidak lancar & Tidak lancar & Tidak lancar & Tidak lancar \\
\hline \multirow{3}{*}{\begin{tabular}{lrr} 
Menuliskan & \multicolumn{2}{c}{ langkah-langkah } \\
penyelesaian & soal & dengan \\
menggunakan rumus &
\end{tabular}} & Akurat & Akur & Tidak akurat & Tidak akurat \\
\hline & Lengkap & Tidak lengkap & Tidak lengkap & Tidak lengkap \\
\hline & Lancar & Lancar & Tidak lancar & Tidak lancar \\
\hline \multirow{3}{*}{$\begin{array}{l}\text { Menuliskan kembali tahapan-tahapan } \\
\text { penyelesaian soal yang telah } \\
\text { dilakukan sebelumnya }\end{array}$} & Akurat & Akurat & Akurat & Tidak akurat \\
\hline & Lengkap & Lengkap & Lengkap & Tidak lengkap \\
\hline & Lancar & Lancar & Lancar & Tidak lancar \\
\hline
\end{tabular}

Dari tabel di atas, dapat dinyatakan bahwa STT dan STR baik dalam kemampuan komunikasi tertulis, sedangkan SRT cukup baik dalam kemampuan komunikasi tertulis, dan SRR mempunyai kemampuan komunikasi tertulis kurang baik.
2. Analisis data hasil wawancara untuk menemukan kemampuan komunikasi matematika lisan siswa. Gambar di bawah ini merupakan gambar analisis data hasil wawancara subjek STT

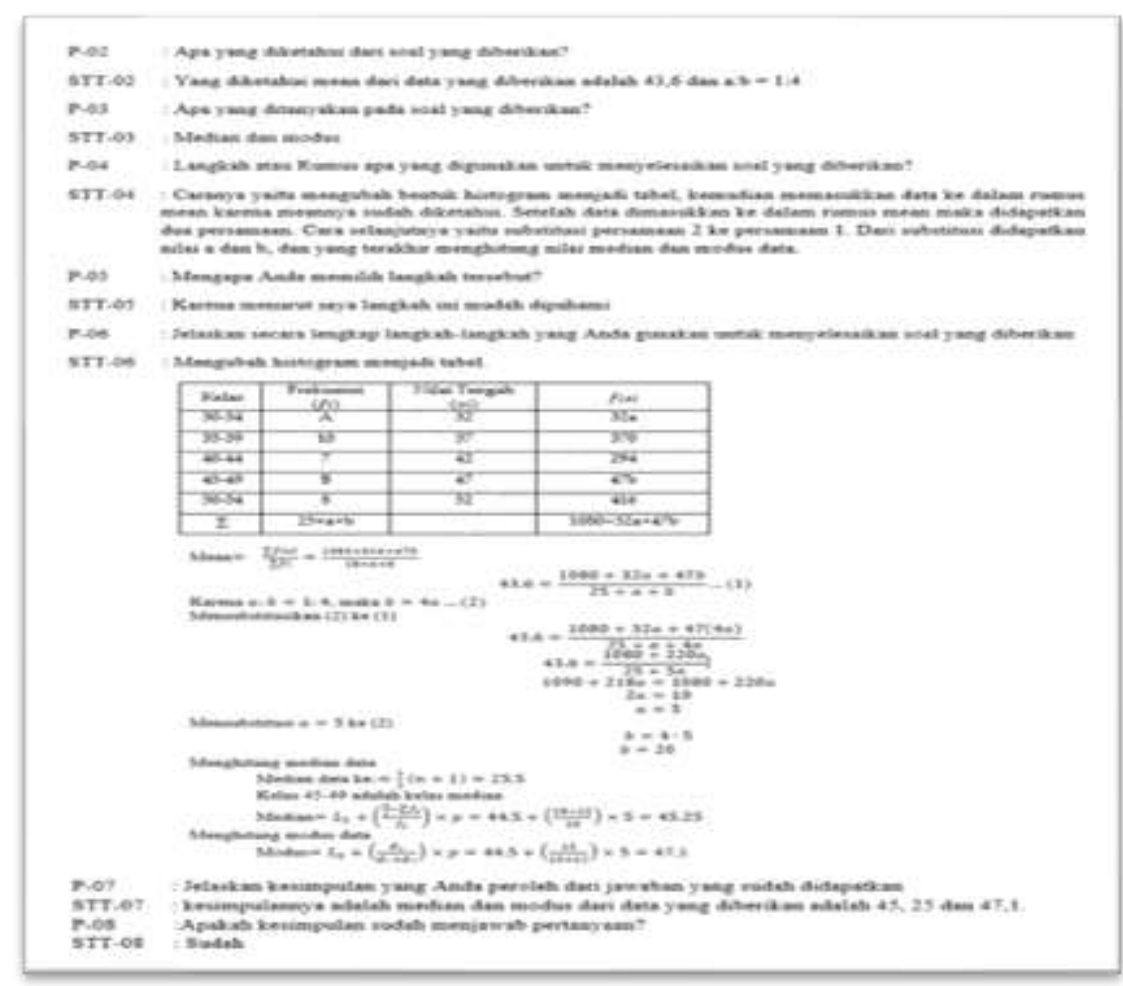

Gambar 3. Analisis Data Hasil Wawancara 
Dari hasil wawancara, STT menyatakan langkahlangkah penyelesaian soal secara akurat dan lengkap (P-02 hingga STT-03). STT memberi tahu langkah-langkah yang akurat dan lengkap (P-04 hingga STT-05). STT melaksanakan langkahlangkah rencana secara akurat dan lengkap (P-06 dan STT-06). STT memberitahu langkah-langkah penyelesaian soal yang telah dilakukan (P-07 hingga STT-08). Kemudian, STT melakukan proses wawancara dengan jelas dan tepat waktu, itu artinya STT melakukan langkah-langkah penyelesaian soal dengan lancar. Dengan langkah yang sama dan analisis yang sama seperti analisis STT sebelumnya, peneliti mendapatkan hasil analisis STR, SRT, SRR. Hasil analisis dapat dilihat pada Tabel 6 .

Tabel 2 Hasil dan Analisis Data Hasil Wawancara

\begin{tabular}{|l|c|c|c|c|}
\hline \multicolumn{2}{|c|}{ Indikator } & \multicolumn{3}{c|}{ Kategori Kecerdasan Intrapersonal-Interpersonal } \\
\cline { 2 - 5 } & STT & STR & SRT & SRR \\
\hline $\begin{array}{l}\text { Menyatakan apa yang diketahui dan ditanyakan } \\
\text { dalam soal yang diberikan }\end{array}$ & Akurat & Akurat & Akurat & Akurat \\
\cline { 2 - 5 } & Lengkap & Lengkap & Lengkap & Lengkap \\
\cline { 2 - 5 } & Lancar & Lancar & Lancar & Lancar \\
\hline $\begin{array}{l}\text { Menyatakan langkah-langkah penyelesaian soal } \\
\text { dengan menggunakan rumus }\end{array}$ & Akurat & Akurat & Akurat & Akurat \\
\cline { 2 - 5 } & Lengkap & Lengkap & Lengkap & Tidak lengkap \\
\cline { 2 - 5 } & Lancar & Lancar & Lancar & Tidak lancar \\
\hline $\begin{array}{l}\text { Menuliskan kembali tahapan-tahapan penyelesaian } \\
\text { soal yang telah dilakukan sebelumnya }\end{array}$ & Akurat & Akurat & Akurat & Akurat \\
\cline { 2 - 5 } & Lengkap & Lengkap & Lengkap & Tidak lengkap \\
\cline { 2 - 5 } & Lancar & Lancar & Lancar & Tidak lancar \\
\hline
\end{tabular}

Dari tabel di atas, dapat dinyatakan bahwa STT, STR, dan SRT baik dalam kemampuan komunikasi lisan, sedangkan SRR mempunyai kemampuan komunikasi lisan kurang baik.

\section{B. Pembahasan}

Kecerdasan intrapersonal dan interpersonal yang ditunjukkan oleh siswa dapat terlihat pada saat siswa melakukan komunikasi, baik komunikasi tulis maupun komunikasi lisan. Dari hasil pengerjaan tes kemampuan komunikasi matematis STT dapat menuliskan langkah-lagkah penyelesaian soal dengan akurat, lengkap, dan lancar. Meskipun di lembar pengerjaan tes kemampuan komunikasi tulis STT tidak menuliskan apa yang diketahui dan apa yang ditanya namun pada saat wawancara STT dapat menyebutkan apa yang diketahui, apa yang ditanya dengan akurat, lengkap, dan lancar. Hal itu sejalan dengan (Lwin, dkk, 2008) bahwa orang yang memiliki kecerdasan intrepersonal biasa menuangkan ide atau pemikirannya dalam bentuk tulisan. Sesuai dengan Safaria (2005) yaitu karakteristik seseorang yang memiliki kecerdasan intrapersonal dan interpersonal tinggi memiliki keterampilan mendengarkan efektif, berbicara efektif, dan menulis secara efektif. Perbedaan dan persamaan kecerdasan intrapersonal dan interpersonal dapat dilihat pada tabel 7.

Tabel 7 Persamaan dan Perbedaan Kecerdasan Interpersonal dan Intrapersonal Masing-masing Subjek

\begin{tabular}{|c|c|c|}
\hline Indikator & $\begin{array}{c}\text { Persamaan } \\
\end{array}$ & Perbedaan \\
\hline 1 & $\begin{array}{l}\text { STT, STR, SRT, dan SRR tidak } \\
\text { menuliskan apa yang diketahui dan apa } \\
\text { yang ditanya dalam lembar pengerjaan } \\
\text { tes kemampuan komunikasi matematis. } \\
\text { Tetapi saat dilakukan wawancara dari } \\
\text { keempat subjek mampu menyebutkan } \\
\text { apa yang ditanya dan apa yang diketahui } \\
\text { dalam soal. }\end{array}$ & 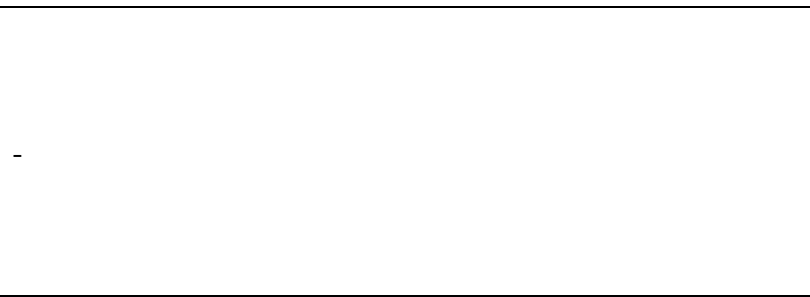 \\
\hline 2 & $\begin{array}{l}\text { STT melakukan perhitungan dengan } \\
\text { jelas menuliskan semua rumus yang } \\
\text { digunakan dalam penyelesaian tes } \\
\text { kemampuan komunikasi matematis yang } \\
\text { diberikan dengan akurat, lengkap, dan } \\
\text { lancar. }\end{array}$ & $\begin{array}{l}\text { STR tidak menuliskan semua rumus yang digunakan dalam } \\
\text { menyelesaikan tes kemampuan komunikasi matematis, namun } \\
\text { STR melakukan perhitungan dengan akurat dan lancar. SRT } \\
\text { menyelesaikan tes kemampuan komunikasi matematis dengan } \\
\text { akurat namun tidak lengkap, karena SRT tidak menuliskan } \\
\text { langkah penyelesaian dengan lengkap serta tidak menuliskan } \\
\text { rumus yang digunakan dalam menyelesaikan tes tersebut. SRR } \\
\text { tidak menuliskan rumus dan langkah yang digunakan dalam } \\
\text { menyelesaikan tes kemampuan komunikasi matematis yang } \\
\text { diberikan. }\end{array}$ \\
\hline 3 & $\begin{array}{l}\text { STT dan STR menuliskan dan } \\
\text { menyebutkan tahapan tahapan apa saja } \\
\text { yang telah dilakukan dalam } \\
\text { menyelesaikan tes kemampuan } \\
\text { komunikasi matematis dengan akurat, } \\
\text { lancar, dan lengkap. }\end{array}$ & $\begin{array}{l}\text { SRT tidak menuliskan tahapan apa saja yang telah dilakukan } \\
\text { dalam menyelesaikan tes kemampuan komunikasi matematis } \\
\text { namun pada saat wawancara SRT menyebutkan tahapan yang } \\
\text { telah digunakan dalam menyelesaikan soal tersebut. SRR tidak } \\
\text { menuliskan tahapan yang telah dilakukan dalam menyelesaikan } \\
\text { soal dan saat wawancara SRR tidak menyebutkan tahapan } \\
\text { tahapan yang telah digunakan dalam menyelesaikan soal. }\end{array}$ \\
\hline
\end{tabular}


Tabel 7 menunjukkan perbedaan dan persamaan kecerdasan intrapersonal dan interpersonal dari keempat subjek, dimana diketahui terdapat banyak perbedaan antara kecerdasan dari subjek kecerdasan baik interpersonal dan intrapersonal keduanya tinggi, kecerdasan intrapersonal tinggi namun kecerdasan interpersonal rendah, kecerdasan intrapersonal rendah namun kecerdasan interpersonal tinggi, dan kecerdasan intrapersonal maupun interpersonal keduanya rendah. Penelitian Febriyanti (2018) menunjukkan hasil yang serupa akibatnya memerkuat hasil penelitian ini mengenai komunikasi matematis dengan kecerdasan intrapersonal dan interpersonal. Dari hasil penelitian tersebut juga terdapat kesamaan dengan hasil penelitian ini yakni SRR tidak dapat menyelesaikan soal yang diberikan dengan langkah penyelesaian yang akurat, lengkap, dan lancar. Perbedaan hasil penelitian ini dengan penelitian Febriyanti (2018) adalah SRT tidak dapat memberikan penjelasan pada setiap langkah penyelesaian. Berdasarkan konsep Possitive Intrapersonal and Interpersonal Functioning yang dikembangkan oleh Barber (2005) salah satu variabel yang dapat menimbulkan perbedaan hasil penelitian adalah tingkat kecerdasan. Tingkat kecerdasan yang dimiliki oleh masing-masing siswa tersebut memungkinkan terjadinya perbedaan kemampuan komunikasi matematis tulis maupun lisan mereka dalam menyelesaikan soal. Hasil penelitian yang telah dilakukan oleh Handayani (2017) menunjukkan hasil siswa dengan kecerdasan intrapersonal dan interpersonal tinggi memiliki kemampuan komunikasi matematika yang baik dalam memecahkan masalah matematika Hasil dari penelitian tersebut memerkuat hasil penelitian ini yang memperlihatkan bahwa siswa dengan kecerdasan intrapersonal rendah dan interpersonal rendah sulit untuk mengkomunikasikan informasi mereka sendiri, tidak semudah siswa dengan kecerdasan intrapersonal tinggi dan interpersonal tinggi dalam menyampaikan informasi.

\section{Simpulan}

Dari hasil penelitian dan pembahasan menampakkan adanya perbedaan dalam menyelesaikan soal statistika dari subjek dengan tingkat kecerdasan intrapersonal dan interpersonal keduanya tinggi, subjek dengan tingkat kecerdasan intrapersonal tinggi namun interpersonal rendah, subjek kecerdasan intrapersonal rendah namun interpersonal tinggi, dan subjek dengan kecerdasan intrapersonal dan interpersonal keduanya rendah. Maka dapat disimpulkan sebagai berikut.

1. Kemampuan komunikasi matematis siswa dalam menyelesaikan soal statistika dengan kecerdasan intrapersonal dan interpersonal tinggi

a. Kemampuan komunikasi matematis tulis Siswa tidak menuliskan apa yag diketahui dan apa yang ditanyakan. Akan tetapi siswa menuliskan langkah penyelesaian soal beserta rumus dengan akurat, lengkap, dan lancar.

b. Kemampuan komunikasi matematis lisan Siswa menyatakan apa yang diketahui dan apa yang ditanyakan secara akurat, lengkap, dan lancar. Siswa memberi tahu langkah-langkah yang dilakukan secara akurat, lengkap, dan lancar serta memberitahu kesimpulan dari penyelesaian soal yang telah dilakukan.

2. Kemampuan komunikasi matematis siswa dalam menyelesaikan soal statistika dengan kecerdasan intrapersonal tinggi dan interpersonal rendah

a. Kemampuan komunikasi matematis tulis Siswa tidak menuliskan apa yag diketahui, apa yang ditanyakan, dan rumus yang digunakan dalam menyelesaikan soal. Akan tetapi siswa menuliskan langkah penyelesaian soal dengan akurat, lengkap, dan lancar.

b. Kemampuan komunikasi matematis lisan Siswa menyatakan apa yang diketahui dan apa yang ditanyakan secara akurat, lengkap, dan lancar. Siswa memberi tahu langkah-langkah yang dilakukan secara akurat, lengkap, dan lancar serta memberitahu kesimpulan dari penyelesaian soal yang telah dilakukan.

3. Kemampuan komunikasi matematis siswa dalam menyelesaikan soal statistika dengan kecerdasan intrapersonal rendah dan interpersonal tinggi

a. Kemampuan komunikasi matematis tulis

Siswa tidak menuliskan apa yag diketahui, apa yang ditanyakan, dan rumus yang digunakan dalam menyelesaikan soal. Akan tetapi siswa menuliskan langkah penyelesaian soal dengan akurat dan lancar, namun tidak lengkap

b. Kemampuan komunikasi matematis lisan Siswa menyatakan apa yang diketahui dan apa yang ditanyakan secara akurat, lengkap, dan lancar. Siswa memberi tahu langkah-langkah yang dilakukan secara akurat dan lancar tetapi tidak lengkap, serta memberitahu kesimpulan dari penyelesaian soal yang telah dilakukan.

4. Kemampuan komunikasi matematis siswa dalam menyelesaikan soal statistika dengan 
kecerdasan intrapersonal dan interpersonal rendah

a. Kemampuan komunikasi matematis tulis

Siswa tidak menuliskan apa yag diketahui, apa yang ditanyakan, dan rumus yang digunakan dalam menyelesaikan soal. Akan tetapi siswa menuliskan langkah penyelesaian soal dengan akurat, namun tidak lengkap dan tidak lancar.

b. Kemampuan komunikasi matematis lisan Siswa menyatakan apa yang diketahui dan apa yang ditanyakan secara akurat, lengkap, dan lancar. Siswa memberi tahu langkah-langkah yang dilakukan secara akurat tetapi tidak lengkap dan tidak lancar.

Berdasarkan hasil deskripsi dan simpulan di atas, dapat disimpulkan bahwa siswa dengan kecerdasan intrapersonal tinggi pada umumnya memiliki kemampuan komunikasi tertulis yang lebih baik daripada siswa dengan kecerdasan intrapersonal rendah. Sedangkan siswa dengan kecerdasan interpersonal tinggi pada umumnya memiliki kemampuan komunikasi lisan yang lebih baik daripada siswa dengan kecerdasan interpersonal rendah.

\section{Saran}

1. Untuk penelitian selanjutnya, perlu menambahkan variabel kontrol lain yaitu kemampuan matematika siswa. Karena subjek penelitian memiliki tingkat kemampuan matematika yang serupa, hal itu dapat mempengaruhi hasil penelitian karena perbedaan kecerdasan intrapersonal dan interpersonal siswa, bukan karena perbedaan kemampuan matematika.

2. Siswa dengan kecerdasan intrapersonal rendah dan kecerdasan interpersonal rendah, sulit untuk mengkomunikasikan informasi mereka sendiri, sehingga mereka memerlukan perlakuan khusus dari guru dan sekolah untuk meningkatkan kecerdasan mereka. Untuk meningkatkan kecerdasan intrapersonal mereka, lebih baik melakukan konseling terjadwal dan mendengarkan tentang kesulitan yang dirasakan oleh siswa. Sedangkan, untuk meningkatkan kecerdasan interpersonal mereka, dapat dilakukan dengan cara memberi mereka kegiatan belajar yang membutuhkan kerja tim dan kegiatan diskusi sehingga siswa dapat lebih akrab satu sama lain.

3. Pada penelitian ini masih terbatas pada kemampuan komunikasi matematis siswa dalam menyelesaikan soal statistika yang dilihat dari kecerdasan intrapersonal dan interpersonal. Untuk penelitian selanjutnya, lebih baik untuk beralih ke materi lain dengan tingkat lain, atau mengubah kecerdasan intrapersonal dan interpersonal ke berbagai kecerdasan lain sehingga ada lebih banyak variasi pada hasil yang akan didapat.

\section{Daftar Pustaka}

Awaludin. 2017. Profil Penalaran Kreatif Siswa SMP Pada Materi Statistika Ditinjau dari Gaya Kognitif Field Dependent dan Field Independent. Jurnal Unnes

Barber, B. 2005. "Positive Interpersonal and Intrapersonal Functioning: An Assesment of Measures among Adolescents". In Kristin A. M. \& Laura H. L (Ed.). 2005. What Do Children Need to Flourish. New York: Springer Science and Bussines Media

Boediono dan Koster, W. 2004. Teori dan Aplikasi Statistika dan Probailitas. Bandung: Remaja Rosdakarya.

Depdiknas. 2008. Kamus Besar Bahasa Indonesia, Jakarta: Balai Pustaka

Febriyanti, R. 2018. "Students' Mathematical Communication Abilities in Mathematical Problem Solving Viewed from Intrapersonal and Interpersonal Intelligences". Jurnal Mathedunesa. Vol. 7(1)

Handayani L. S., Syafriandi, \& Mirna. 2016. Pengaruh Metode Think Aloud Pair Problem Solving (TAPPS) terhadap Kemampuan Komunikasi Matematika Siswa SMA, (online),

(ejournal.unp.ac.id/students/index.php/ pmat/article/ download/1206/898, downloaded 03 November 2019)

Kaselin, Sukestiyarno, \& Waluya, B. 2017. Kemampuan Komunikasi Matematis pada Pembelajaran Matematika dengan Strategi React Berbasis Etnomatematika, (online), (https://journal.unnes.ac.id/ sju/index.php/ujmer/article/view downloaded 03 November 2019)

/2700,

Kementerian Pendidikan dan Kebudayaan Indonesia. 2013. Matematika. Jakarta: Kementerian Pendidikan dan Kebudayaan

Lwin, M., Khoo, A., Lyen, K., \& Sim, C. 2008. How to Multiply Your Child's Intelligence. Indonesia: PT Macanan Jaya Cemerlang

Moore, M. G. (1997). Handbook of Distance Education: Second Edition. USA: Lawrence Erlbaum Associates.

Morrale, S. P dan Pearson, J. 2008. "Why Communication Education is Important: The Centrality of the Discipline in the 21st 
Century". Journal Communication Education. Vol. 57 (2): pp. 224-240.

National Council of Teacher of Mathematics. 1989. Curriculum and Evaluation Standards for School Mathematics. Reston, Virginia: NCTM

National Council of Teacher of Mathematics. 2000. Principles and Standards for School Mathematics. Reston, Virginia: NCTM

Organization of Economic and Cooperation Development. 2013. Draft Mathematics Framework. PISA.

Rausch, A. 2017. "Complexity, Accuracy, Fluency as a Communication Paradigm: From Theory to Instructional Curriculum". Japanese Journal of Communication Studies. Vol. 45 (2): pp. 115-127.

Rumsey, D. 2002. "Statistical Literacy as a Goal for Introductory Statistics Courses". Journal of Statistics Education, (Online), Vol. 10(3).
Safaria, T. 2005. Interpersonal Intelligence: Metode Pengembangan Kecerdasan Interpersonal Anak. Yogyakarta: Amara Books

Saiman, S. 2016. "Analisis Kesulitan Siswa dalam Belajar Statistik Khususnya pada Histogram”. AKSIOMA: Jurnal Pendidikan Matematika. Vol.5(2).

UNESA. 2017. Pedoman Penulisan Artikel Jurnal. Surabaya: Lembaga Penelitian Universitas Negeri Surabaya

Zubaidah, S. 2016. "Keterampilan Abad Ke-21: Keterampilan yang Diajarkan Melalui Pembelajaran". Makalah disajikan dalam Seminar Nasional Pendidikan dengan tema "Isu-isu Strategis Pembelajaran MIPA Abad 21". Sintang-Kalimantan Barat: ResearchGate 